\title{
SEJARAH PERKEMBANGAN KESENIAN TARI GAPLIK DI DESA KENDUNG KECAMATAN KWADUNGAN KABUPATEN NGAWI TAHUN 1966-2014
}

\author{
Anjar Mukti Wibowo \& Shoffikha Cahyanul Janah*
}

\begin{abstract}
Abstrak
Keberadaan tari gaplik diperkirakan sudah ada sejak Indonesia belum merdeka. Gaplik ini merupakan singkatan dari gambaran petunjuk liwat kesenian. latar belakang ditarikannya tari ini karena desa Kendung mengalami bencana pagebluk dan huru hara, dan setelah diadakan tari gaplik keadaan menjadi lebih baik. Tari Gaplik di desa Kendung ditarikan pada hari Jumat Wage. Orang yang menarikannya saat ini adalah saudara Hartono, yang menjadi penerus ayahnya yaitu saudara Kasno. Pada tahun 1966 tari gaplik mulai ditampilkan dalam acara-acara Nyadran di desa-desa yang lain. Diantaranya adalah desa Mbayem, desa Kincang kabupaten Magetan, desa Suratmajan Maospati, dan desa Kinandang kabupaten Magetan. Pada tahun 2005 tari gaplik mulai mewakili kota Ngawi dalam festival kesenian tradisional di Surabaya. Pada bulan januari 2006 tari gaplik kembali mengikuti festival kesenian tradisional se jawa timur di Surabaya. Setelah itu pada tahun 2008 tari gaplik dipercaya kembali dan diikut sertakan dalam lomba kesenian tradisional se Jawa Timur di Bojonegoro, dan untuk ke empat kalinya tari gaplik kembali diikutkan dalam lomba pada Agustus 2010 di Kediri. Setelah dikenal luas oleh masyarakat dan menjadi tari tradisional yang menghibur serta menarik banyak penonton, pada bulan Juni 2013 tari gaplik ditampilkan dalam hari jadi Ngawi di Benteng Pendem kota Ngawi.
\end{abstract}

\section{Kata Kunci : Sejarah, Kesenian,Tari Gaplik}

Pendahuluan

Indonesia adalah negara yang memiliki banyak pulau. Dalam setiap pulau yang tersebar di Indonesia terdapat berbagai daerah yang penduduknya mempunyai ciri khas yang tidak sama. Keadaan alam, beragamnya agama, sistim sosial, kondisi ekonomi dan lain sebagainya membawa pengaruh kepada pola pikir yang bermacam-macam. Sehingga pola pikir tersebut melahirkan watak serta tingkah laku yang berbeda sesuai tantangan dan keadaan yang mereka hadapi sehari-hari. Perbedaan yang ada di Indonesia ini merupakan sesuatu yang baik karena menandakan bahwa Indonesia memiliki keanekaragaman budaya.

Edward Burnett Tylor (dalam Elly M Setiadi, Kama, Ridwan 2007: 27) mengatakan "kebudayaan merupakan keseluruhan yang kompleks, yang di dalamnya terkandung pengetahuan, kepercayaan, kesenian, moral, hukum, adat istiadat, dan kemampuan-kemampuan lain yang didapat seseorang sebagai anggota masyarakat". Keanekaragaman budaya yang dimiliki Indonesia ini tersebar pada seluruh wilayah di Indonesia. Setiap daerah memiliki budaya dan adat dengan keunikan yang berbeda-beda. Keunikan tersebut menjadi ciri khas dari setiap adat dan 
budaya yang dimiliki oleh masing-masing daerah.

Dari berbagai daerah yang tersebar di Nusantara, Jawa Timur merupakan salah satu daerah yang memiliki banyak adat dan budaya yang unik. Masyarakat Jawa Timur umumnya masih kental dengan kepercayaan akan adat dan budaya yang diwariskan oleh nenek moyang mereka. Masih banyak masyarakat yang tetap melestarikan adat dan budaya yang mereka miliki. Ngawi adalah salah satu Kabupaten di Jawa Timur yang memiliki beberapa kesenian tradisional yang merupakan warisan budaya. Kesenian yang dimiliki diantaranya seperti tari orek-orek, tari pentul, tari kecetan serta tari gaplik.

Kesenian merupakan salah satu kebutuhan manusia yang tergolong dalam kebutuhan integratif adalah menikmati keindahan, mengapresiasi dan mengungkapakan perasaan keindahan. Kebutuhan ini muncul disebabkan adanya sifat dasar manusia yang ingin mengungkapkan jati dirinya sebagai makhluk hidup yang bermoral, berselera, berakal, dan berperasaan. Kebutuhan estetik serupa dengan pemenuhan kebutuhan primer dan sekunder yang dilakukan manusia melalui kebudayaannya. Dalam memenuhi kebutuhan estetik ini, kesenian menjadi bagian integral yang tak terpisahkan dengan kebudayaan (Geertz dalam Nooryan Bahari, 2008: 45). Hal di atas dapat kita lihat bahwa kesenian dapat digunakan manusia sebagai sarana untuk memenuhi kebutuhan akan hiburan. Kesenian sendiri tidak dapat terpisahkan dengan budaya yang didapatkan oleh manusia sebagai anggota masyarakat. Melalui kesenian berupa musik, tarian, atau lukisan manusia memperoleh suatu keindahan yang dapat memberikan hiburan dan kesenangan.

Seni tari merupakan seni yang dapat diserap melalui indra penglihatan, dimana keindahannya dapat dinikmati dari gerakangerakan tubuh, terutama gerakan kaki dan tangan, dengan ritme-ritme teratur, yang diiringi irama musik yang di serap melalui indra pendengaran. Berdasarkan jenisnya, tari dibagi menjadi tari rakyat, tari klasik, dan tari kreasi baru. Pertama, tari rakyat hidup dan berkembang dikalangan rakyat seperti tari Tayub dari Jawa Tengah dan Jawa Timur, tari Gandrung Banyuwangi dari Blambangan Jawa Timur, Joged Bumbung dari Bali, Suhu Reka-reka dari Maluku, dan lain-lain.

Kedua, tari klasik hampir tidak dapat dipisahkan dengan istana atau kraton, mengingat di tempat itulah pertunjukan ini lahir dan berkembang memasuki proses kristalisasi estetis yang tinggi. Contohnya adalah tari klasik dari Yogyakarta dan Surakarta, antara lain tari Bedhaya, Srimpi, Beksan, Lawung dan wayang wong. Ketiga tari kreasi baru merupakan upaya memasyarakatkan seni istana dan seni ritual berlabel nasional (2008:57) 
Dari berbagai tarian di atas Kabupaten Ngawi memiliki tarian yang tergolong pada tari rakyat, salah satunya adalah tari Gaplik. Tari Gaplik digunakan oleh masyarakat desa Kendung Kecamatan Kwadungan sebagai tarian dalam ritual Nyadran atau bersih desa. Tarian tersebut dilakukan di depan arca yang diyakini sebagai makam leluhur mereka dahulu. Arca tersebut diyakini sudah ada sejak masa Hindu-Budha. Masyarakat Desa Kendung sendiri menyebut arca itu dengan nama makam mbah Budho. Namun setelah agama Islam berkembang di daerah Kendung Kwadungan masyarakat khawatir adanya arca tersebut akan mengundang kemusrikan, maka arca dikubur di dalam tanah.

Tari Gaplik ini masih berkembang dan dilestarikan hingga saat ini. Pada tahun 1966 di tengah banyaknya seni pertunjukan yang muncul, ternyata tari gaplik mampu memunculkan ketertarikan bagi masyarakat desa lain untuk menyaksikannya. Ketertarikan tersebut muncul karena tari gaplik memiliki keunikan dengan menampilkan cerita dan lelucon di dalam gerakan tari. Dari ketertarikan tersebut menjadikan tari gaplik semakin dikenal dan mendapat tawaran untuk mengisi acara nyadran di desa-desa yang lain. Tarian ini dilakukan oleh seorang laki-laki yang diberi nama pakgaplik sebagai pemain utama dalam tarian tersebut, dengan ditemani oleh seorang wanita. Wanita dalam cerita tersebut dikisahkan sebagai seseorang yang digandrungi oleh pak gaplik.

Dalam tari gaplik ini tidak semua orang dapat menarikannya karena hanya orang yang memiliki darah keturunan dari penari pertama saja yang diperbolehkan. Hal ini dikarenakan tari Gaplik ini masih dikeramatkan dan merupakan tarian yang sakral. Di desa Kendung tarian ini ditarikan oleh saudara Hartono sebagai generasi keempat. Dari tahun ketahun tarian Gaplik mengalami berbagai perkembangan namun dalam perkembangannya tari Gaplik tetap tidak meninggalkan atau merubah dari gerakan, musik, serta lagu wajib yang menjadi ciri khas dari tari Gaplik.

Tari Gaplik merupakan kesenian yang menjadi aset budaya yang dimiliki oleh Indonesia. Tari ini memiliki sesuatu yang menarik di dalamnya, seperti gerakangerakannya yang memiliki makna yang unik, pakaian dan kostum yang mengandung arti tersendiri serta di dalam bagian tarian juga terdapat cerita yang menghibur para penonton. Bagi generasi penerus tari Gaplik menjadi salah satu pembelajaran yang penting untuk menambah pengetahuan tentang prilaku kehidupan masyarakat masa lalu dan dapat mengambil pembelajaran di dalamnya untuk kehidupan saat ini. Tari ini juga menambah pengetahuan akan warisan budaya yang dimiliki Indonesia. Pembelajaran dari makna-makna yang terkandung didalamnya dapat kita ambil agar kita lebih kritis dan 
menjadi manusia yang berbudaya sehingga dapat hidup lebih baik dan bijaksana. Melihat tari Gaplik merupakan tarian yang masih dilestarikan hingga saat ini dan di dalamnya memiliki keunikan serta arti penting untuk dipelajari, maka dari sini penulis tertararik dan merasa penelitian tentang perkembangan tari Gaplik ini perlu untuk dilakukan.

\section{Tujuan Penelitian}

Berdasarkan rumusan masalah di atas maka tujuan penelitian ini adalah untuk mendiskripsikan sejarah dan perkembangan tari Gaplik di Desa Kendung Kecamatan Kwadungan Kabupaten Ngawi tahun 1966-2014.

\section{Kajian Pustaka}

\section{A. Sejarah Kesenian}

Koentjaraningrat (dalam Tjetjep Rohandi, 2000: 3) mengungkapkan kesenian telah menyertai kehidupan manusia sejak awal-awal kehidupan dan sekaligus juga merupakan bagian yang tak terpisahkan dari seluruh kehidupan manusia. Menurut Taylor (dalam Alo Liliweri, 2007: 125) seni dipandang sebagai sebuah proses yang melatih ketrampilan, aktivitas manusia untuk menyatakan atau mengkomunikasikan perasaan atau nilai yang dia miliki. Kesenian merupakan unsur integrative yang mengikat dan mempersatukan pedoman-pedoman bertindak yang berbeda-beda menjadi suatu desain yang bulat, menyeluruh, dan operasional serta dapat diterima sebagai hal yang bernilai (Tjetjep Rohendi, 2000: 9).

Dalam mengamati perkembangan seni di Indonesia dari masa lampau sampai ke era globalisasi, diperlukan penelusuran sejarahnya sejak masa prasejarah sampai masa sekarang ini. dengan melihat seni pertunjukan Indonesia di masa silam akan dapat diketahui pasang surutnya berbagai bentuk seni pertunjukan.

Edi Sedyawati (2007: 290-292) mengatakan Indonesia secara keseluruhan dapat dipilah zaman-zaman budaya sebagai berikut

1. Masa Prasejarah Awal

.... Pada zaman ini di Indonesia tidak ditemukan data mengenai kemungkinan adanya seni pertunjukan (berbeda dengan peninggalan palaeolithik di Eropa di mana terdapat lukisan gua yang menggambarkan figure-figur manusia yang seperti dalam sikap menari)

2. Zaman Prasejarah Akhir .... Pada beberapa benda logam hasil zaman ini terdapat sejumpah penggambaran,yang berdasar analogi etnografik, dapat ditafsirkan sebagai gambar-gambar orang menari dengan mengenakan hiasan kepala bulubulupanjang dan mungkin mengenakan topeng, baik dalam rangka upacara maupun tarian, dapat dikenali dalam berbagai benda tinggalan prasejarah masa tersebut. periksa misalnya 
topeng/gambar wajah pada nekara, kapak perunggu, sarkofag, dan arca menhir. Lukisan gua pada zaman inipun menggambarkan figure-figur manusia yang seperti menari.

3. Masa Hindu-Budha

Zaman ini memperlihatkan lonjakan data berkenaan dengan seni pertunjukan. Hal ini lebih-lebih didukung oleh terdapatnya sumbersumber tertulis. Akulturasi dengan kebudayaan India, yang membawa agama Hindu dan Budha sebagai penanda utamanya, memperlihatkan juga pengaruh besar di bidang seni, termasuk seni pertunjukan. Relief-relief candi memperlihatkan adegan-adegan dimana orang menari dan bermain musik ....

4. Zaman Islam

Zaman ini memperlihatkan suatu masukan tersendiri dalam perkembangan seni pertunjukan di Indonesia, khususnya dalam seni musik dengan ciri khasnya berupa permainan rebana ....

5. Zaman Kolonial

Kolonialisme di Indonesia terjadi karena kedatangan orang-orang Eropa, khususnya Belanda, dan untuk masa singkat Inggris, .... Bersamaan dengan kedatangan mereka bangsa Indonesia diperkenalkan dengan gagasan-gagasan baru, seperti prinsip-prinsip keilmiahan, sistem pendidikan formal, serta juga bentuk-bentuk kesenian Eropa. Dalam seni pertunjukan ragam baru yang diperkenalkan adalah apa yang disebut toneel dan musik diatonik.

6. Zaman Kemerdekaan Sebagai Republik Indonesia

Zaman Indonesia merdeka ini memperlihatkan kekhasan dalam perkembangan seni, termasuk seni pertunjukan. Di satu sisi bentuk-bentuk baru yang khususnya diambil alih dari kebudayaan Eropa digunakan untuk memperkembangkan suau ragam baru kesenian yang sekaligus juga menjadi suatu "kesenian nasional". Sebagai contoh dapat disebutkan betapa lagu kebangsaan RI, serta lagu-lagu perjuangan, maupun juga bentukbentuk khas yang berkembang disini seperti keroncong dan dangdut, semuanya berlandaskan sistem nada diatonik.

Perkembangan politik di tanah air ternyata juga mempunyai dampak yang sangat besar terhadap perkembangan seni pertunjukan. Soedarsono (2010 : 93-117) menjelaskan pengaruh politik terhadap seni pertunjukan di Indonesia. Pada Era Orde Lama Tahun 1950-an sampai tahun 1960an, partai komunis Indonesia (PKI) sangat berpengaruh terhadap perkembangan seni pertunjukan. Berbagai seni pertunjukan yang mampu meraih penonton banyak ditunggangi oleh partai ini sebagai media propaganda. Brandon (dalam Soedarsono, 
2010: 93) menggambarkan berbagai bentuk seni pertunjukan yang mampu meraih masa, seperti ketoprak dan ludruk di Jawa, menjadi rebutan antara dua partai yang bersaing, yaitu Partai Nasional Indonesia (PNI) dan Partai Komunis Indonesia (PKI). Pada masa itu bermunculan berbagai bentuk tari yang menggambarkan kehidupan rakyat, seperti misalnya Tari Tani, Tari Nelayan, Tari Gotong-royong, dan sebagainya. Tema-tema 'ganyang tuan tanah', 'ganyang kolonialisme', dan 'ganyang imperialisme', banyak mewarnai pertunjukan-pertunjukan ketoprak dan ludruk yang berada di bawah naungan PKI

Masa Orde Baru dan Globalisasi dengan gagalnya pemberontakan PKI, masa Orde Baru yang lahir di persada Nusantara memberi harapan cerah. Para seniman dengan bebasnya mulai mengekspresikan karya-karya yang menampilkan tema-tema serta gaya ungkap sesuai dengan gejolak nurani mereka. Akan tetapi di tengahtengah masa Orde Baru makin hari korupsi makin bertambah merebak dimana-mana. Akibatnya pertunjukan-pertunjukan yang cenderung mengkritik keadaan ini selalu dibungkam dan akhirnya agar selamat kritik-kritik selalu dilakukan secara terselubung.

Seni Pertunjukan di Era Reformasi, dengan hadirnya Era Globalisasi para seniman memiliki kebebasan untuk menampilkan gaya yang mereka inginkan. Akibatnya timbulah semacam arus perkembangan seni yang lazim disebut dengan multikulturalisme atau pluralisme, yang menghargai karya seni dengan gaya apapun dan dari negara manapun. Seni istana tidak menjadi kiblat lagi, demikian pula aliran-aliran seni dari mancanegara. Dalam bidang seni pertunjukan setiap kelompok etnis di Indonesia ingin menampilkan jati diri mereka. Ini tampak apabila pemerintah menyelenggarakan Festifal Kesenian Daerah Tingkat Nasional yang diadakan setiap tahun, dan juga Parade Tari Daerah yang selalu dipanggungkan dalam acara menyongsong hadirnya Tahun Baru

\section{B. Kesenian Tradisional}

\section{Pengertian Kesenian Tradisional}

Kasim Achmad (dalam Juju Masunah dan Tati Narawati, 2003: 131) menjelaskan bahwa kesenian tradisional adalah suatu bentuk seni yang bersumber dan berakar serta telah dirasakan sebagai milik sendiri oleh masyarakat dan lingkungannya. Pengolahannya berdasarkan atas citacita masyarakat pendukungnya. Cita rasa yang dimaksudkan adalah nilai kehidupan tradisi, pandangan hidup, pendekatan falsafah, rasa etis dan estetis, serta ungkapan budaya lingkungan. Hasil kesenian tradisional diterima sebagai tradisi, pewarisan yang dilimpahkan dari angkatan tua ke angkatan muda. Kesenian lokal yang secara umum dikenal sebagai kesenian 
tradisional adalah jenis kesenian yang hidup dominan dikalangan suku bangsa tertentu. Kesenian tradisional menjadi bagian dari kehidupan secara menyeluruh dalam upacara-upacara ritual kehidupan (Tjetjep Rohendi Rohidi, 2000: 209)

SD Humardani (dalam Juju Masunah dan Tati Narawati, 2003: 132) mengatakan bahwa seni tradisi adalah seni yang berkembang di keraton atau dipusat-pusat kekuasaan, tumbuh berates-ratus tahun lalu, bentuknya mendetail. Tari atau musik tradisi dianggap sesuatu yang mempunyai standar tertentu, mutlak adanya, dan tidak berubah sepanjang masa.

Ferianto (dalam Juju Masunah dan Tati Narawati, 2003: 133) berpendapat lain menurutnya sebuah tradisi tidak pernah berhenti. Ia senantiasa berkembang bersama dengan situasi dan konteks sosial yang melingkupinya. Tidak pernah ada suatu tradisi yang tidak berubah. Jika ada tradisi yang tidak berubah berarti tradisi tersebut telah selesai bahkan mati. Dalam kebudayaan global setiap tradisi bersentuhan dengan tradisi yang lain. Setiap tradisi berhubungan, bersentuhan, dan berinteraksi dengan tradisi yang lain.

Dari berbagai penjelasan tentang kesenian tradisional di atas dapat di simpulkan bahwa kesenian tradisional merupakan keanekaragaman budaya yang sudah menjadi bagian hidup masyarakat. Kesenian tradisional merupakan karya seni budaya yang dikagumi masyarakat karena mempunyai keunikan yang berbedabeda yang di dalamnya juga terkandung kearifan dan nilai-nilai mulia.

Tari Gaplik juga merupakan salah satu kesenian tradisional yang menjadi warisan budaya yang di dalamnya mengandung nilai kehidupan tradisi serta ungkapan budaya lingkungan. Tari Gaplik yang merupakan kesenian lokal atau tradisional ini telah menjadi bagian dari kehidupan masyarakat desa Kendung kecamatan Kwadungan sebagai kesenian yang digunakan dalam upacara ritual atau nyadran yang dilakukan setiap tahunnya.

\section{Macam-macam Kesenian Tradisional}

Edi Sedyawati (2007: 399) menjelaskan kesenian dapat dipilah dalam berbagai cabang seni. Untuk masa Jawa Kuno cabang-cabang seni yang dapat diperoleh datanya adalah seni rupa (termasuk arsitektur), kesusastraan, tari, teater, dan dalam batas tertentu musik.

Tjetjep Rohendi (2000 : 209210) juga membedakan tiga jenis kesenian di Indonesia :

1. Kesenian yang bersifat lokal, yaitu jenis kesenian yang hidup dominan 
dikalangan suku bangsa tertentu. Kesenian jenis ini seringkali menjadi bagian dari kehidupan secara menyeluruh (dalam upacaraupacara ritual kehidupan) diantara sesama warga masyarakat yang terisolasi (mengisolasikan diri).

2. Jenis kesenian umum, kesenian ini hidup dalam suasana pergaulan seni di tempat-tempat umum dalam suasana pergaulan atau pertemuan diantara sesama warga masyarakat yang berbeda asal suku bangsa dan golongan sosialnya.

3. Kesenian formal, yaitu kesenian resmi (diresmikan oleh pemerintah atau oleh kekuasaan negara) baik ditingkat regional maupun nasional, yang dipandang atau ditetapkan sebagai kesenian yang mewakili kesenian regional atau nasional.

Dari ketiga jenis kesenian yang telah dijelaskan di atas tari Gaplik merupakan jenis kesenian yang bersifat lokal. Hal ini karena tari Gaplik hidup dikalangan masyarakat tertentu yaitu masyarakat desa Kendung, dimana tari Gaplik ini merupakan bagian dari hidup mereka dan menjadi salah satu kegiatan yang wajib dilakukan sebagai pengisi acara dalam Nyadran di desa Kendung.

$$
\text { Soedarsono (2010: 120) }
$$

mengungkapkan di negara-negara yang sedang berkembang, dalam tata kehidupannya masih banyak mengacu ke budaya agraris, sehingga seni pertunjukannya banyak yang memiliki fungsi ritual. Terlebih apabila penduduknya menganut agama yang selalu melibatkan seni dalam ibadahibadahnya, seperti misalnya penduduk di pulau Bali.

Seni pertunjukan yang berfungsi sebagai ritual di Indonesia banyak berkembang dikalangan masyarakat yang dalam tata kehidupannya masih mengacu pada nilai-nilai budaya agraris, serta masyarakat yang memeluk agama yang dalam kegiatan-kegiatan ibadahnya sangat melibatkan seni, seperti misalnya masyarakat Bali yang beragama Hindu Dharma.

Soedarsono (2010: 126-152) menyebutkan beberapa diantara macam-macam kesenian tradisional yang memiliki fungsi ritual adalah:

a. Tari Rejang dan Baris

Tari rejang adalah tari wanita di Bali yang memiliki kadar ritual yang sangat tinggi. Tari ini berfungsi sebagai tari penyambutan kedatangan para dewa, yang diundang untuk turunke pura, yang disusul dengan tari baris. Baris juga berfungsi sebagai tari penyambutan kepada para dewa serta sebagai pengawal para dewa yang diundang dalam upacara piodalan. Rejang maupun baris merupakan tari sakral yang dipersembahkan kepada para 
dewa pada upacara peodalan pelaksanaannya juga memerlukan tempat terpilih, hari terpilih, penari terpilih, dilengkapi seperangkat sesaji, busana khas dan bukan merupakan pertunjukan yang mengutamakan penampilan secara estetis ....

b. Wayang Wong

Wayang wong adalah nama drama tari yang terdapat $\mathrm{di}$ beberapa daerah di Indonesia. Di Bali wayang wong merupakan drama tari yang menggunakan dialog bahasa Kawi yang selalu menampilkan wiracarita Ramayana. Di Jawa Tengah istilah ini dipergunakan untuk menyebut pertunjukan drama tari berdialog bahasa Jawa prosa, yang biasanya membawakan lakon-lakon dari wiracarita Mahabharata atau Ramayana, yang dicipta oleh Adipati Mangku Nagara I pada perempat ketiga abad ke-18. Pada akhir abad ke-19 pertunjukan istana ini berhasil dikeluarkan dari tembok istana oleh seorang pengusaha Cina kaya bernama Gan Kam. Apabila dilacak sejarahnya sebenarnya pertunjukan drama tari yang bernama wayang wong itu sudah sangat tua usianya. Prasasti Jawa Kuna yaitu prasasti Wimalasrama yang berangka tahun 930 Masehi.
Yang telah menyebut pertunjukan ini dengan istilah Jawa Kuna wayang wwang ....

c. Wayang Kulit Ruwatan

Masyarakat Indonesia yang masih percaya tata nilai kebudayaan agraris, banyak upaya mereka menanggulangi ancaman bahaya yang tidak diharapkan dengan cara tradisional, yaitu dengan cara menyelenggarakan wayang kulit dengan lakon tertentu. Tradisi upacara seperti ini di Jawa dan Bali disebut ruwatan, sedangkan di kalangan masyarakat Madura disebut rokat. Namun antara masyarakat Jawa dan Bali terdapat perbedaan yang sangat besar mengenai siapa saja yang perlu di upacarai dengan menyelenggarakan ruwatan. Walaupun di Jawa dan Bali caranya hampir sama yaitu dengan menyelenggarakan pertunjukan wayang kulit dengan cerita kelahiran Batara Kala yang dipergunakan sebagai perlambangan 'bahaya', namun cara memperkokoh tradisi digunakan mitologi dan legenda yang berbeda .... W.H. Rassers (dalam Soedarsono, 2010: 152) menjelaskan bahwa pertunjukan wayang kulit untuk ruwatan oleh orang Jawa tradisional 


\author{
dipergunakan untuk \\ membebaskan manusia dari sial \\ keberadaannya di dunia ini dari \\ ancaman kekuatan supernatural \\ yang tak kelihatan ....
}

Seperti yang telah disebutkan di atas beberapa dari macam-macam kesenian tradisional yang memiliki fungsi ritual, tari Gaplik juga menjadi salah satu kesenian tari yang di gunakan dalam acara bersih desa atau nyadran yang bertujuan untuk membersihkan desa dari hal-hal buruk yang dapat mengganggu kelancaran kehidupan masyarakatnya baik dalam kesehatan maupun riski yang akan mereka peroleh pada tahun yang akan datang. Selain itu juga menjadi salah satu persembahan sebagai ungkapan syukur atas apa yang diperoleh baik kesehatan maupun hasil panen sebagai riski yang mereka dapatkan pada satu tahun tersebut.

\section{Faktor-faktor yang Mempengaruhi} Perkembangan Kesenian Tradisional

Adapun penyebab dari hidup matinya sebuah seni pertunjukan ada bermacam-macam. Ada yang disebabkan oleh perubahan yang terjadi di bidang politik, ada yang disebabkan oleh masalah ekonomi, ada yang karena terjadi perubahan selera masyarakat penikmat dan ada yang karena tidak mampu bersaing dengan bentuk-bentuk pertunjukan yang lain

(Soedarsono, 2010: 1)

Kenyataan yang saat ini terjadi dan memprihatinkan adalah bahwa banyak jenis kesenian tradisional yang sekarang ini sekarat atau bahkan mati. Terdapat dua faktor mengapa hal itu terjadi yaitu faktor yang berasal dari luar (faktor eksternal) dan yang berasal dari dalam dirinya (faktor internal).

a. Faktor eksternal

Faktor eksternal dipicu oleh gelombang perubahan yang melanda dunia mencuat produk-produk kesenian global yang menghibur, mudah dicerna, gampang ditiru, enak dirasakan, disebarluaskan oleh media masa dan didukung oleh modal besar, sehingga hal ini menjadi penyebab ketersudutan seni tradisi. Produk-produk kesenian global telah merampas selera sebagian besar warga dunia yang seolah-olah mereka digiring kedalam cita rasa etnis homogeny yang dikendalikan lingkaran pemegang modal. Akibatnya lambat laun masyarakat mulai lupa bahwa mereka memiliki kesenian tradisional.

b. Faktor internal

Arus bebas masuknya produkproduk kesenian global tersebut telah memunculkan rasa tidak 
percaya diri dari para pewaris aktif kesenian tradisional karena semakin menjauhi mereka.

Disamping itu para seniman tradisi kurang sigap menanggapi perubahan yang terjadi, sehinga kesenian tradisional yang mereka kemas dan suguhkan terkesan statis dan monoton, baik isi maupun tampilannya. Jika terjadi inovasi di dalamnya hal tersebut biasanya sangat bernuansa dan mengekor produk-produk budaya global yang sedang ngetren dan digemari sehingga yang muncul bukan citra tipikal (Ayu Sutarto, 2004: 2-3)

Dari beberapa faktor yang mempengaruhi perkembangan kesenian tradisional yang telah dijelaskan di atas baik internal maupun eksternal, tari gaplik juga merupakan kesenian tradisional yang mengalami berbagai tantangan tersebut.

Menurut saudara Hartono (penari tari Gaplik) salah satu cara dalam menghadapi tantangantantangan tersebut adalah dengan diadakan perpaduan antara kesenian tradisional dengan sentuhan modernitas tanpa meninggalkan kekhasan dari kesenian tradisional itu sendiri. Sehingga mampu menghibur dan menyuguhkan kesenian yang disukai masyarakat.

\section{Metode Penelitiaan}

\section{A. Tempat Dan Waktu Penelitian}

1. Tempat Penelitian

Penelitian ini dilaksanakan

di Desa Kendung, Kecamatan Kuwadungan, Kabupaten Ngawi. Desa Kendung berjarak kurang lebih 15 km dari pusat Kota Ngawi. Desa Kendung ini dikelilingi oleh persawahan dan sebagian besar masyarakatnya bermata pencaharian sebagai petani. Dipilihnya tempat ini menjadi lokasi penelitian karena di Desa Kendung terdapat kesenian tradisional yaitu tari Gaplik yang merupakan tarian yang masih dijaga dan dilestarikan oleh masyarakat Desa Kendung hingga saat ini.

Sebagai daerah yang
mayoritas penduduknya petani,
wilayah Kabupaten Ngawi
merupakan daerah yang masih
menjunjung adat istiadat yang
dimiliki. Salah satu kesenian
daerah yang khas dan berkembang
hingga saat ini adalah tari gaplik.
Masyarakat meyakini kesenian ini
memiliki pengaruh terhadap
kehidupan mereka baik dalam
ekonomi, kesehatan, dan
kesejahteraan hidup.

Sebagai daerah yang

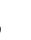


2. Waktu Penelitian

Penelitian dilaksanakan pada bulan Februari-Juni 2014. Adapun pelaksanaan jadwal diawali dari tahap persiapan sebelum ke lapangan, penelitian lapangan, pengumpulan data, analisis data dan penyusunan laporan.

\section{B. Pendekatan dan Jenis Penelitian}

1. Pendekatan Penelitian

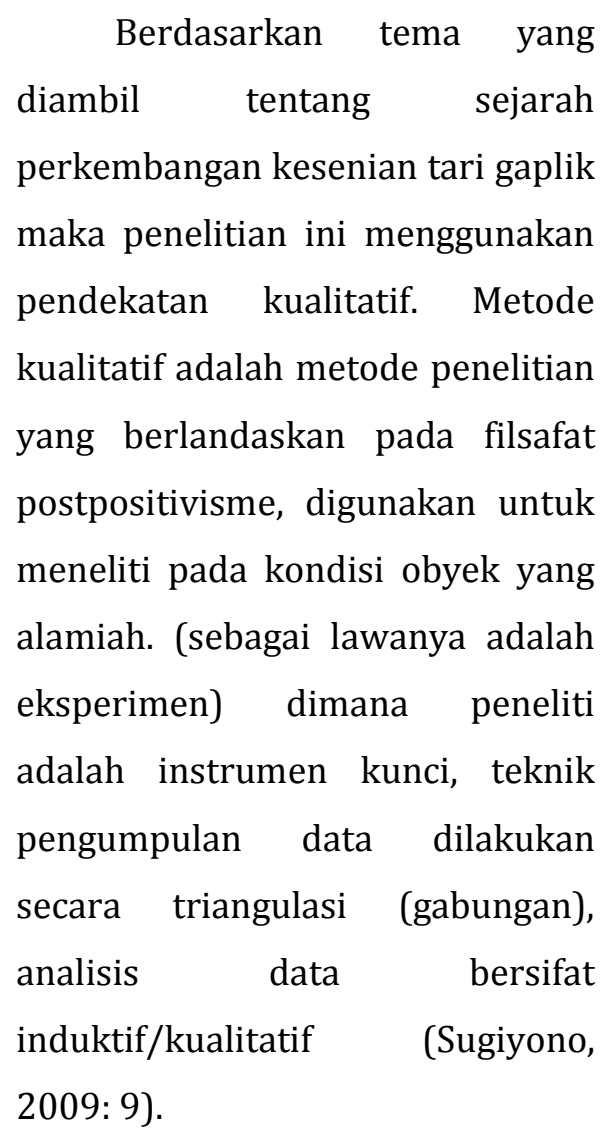

2. Jenis Penelitian

Jenis penelitian deskriptif kualitatif adalah suatu bentuk penelitian yang paling dasar. Ditunjukan untuk mendeskripsikan atau menggambarkan fenomenafenomena yang ada, baik fenomena yang bersifat alamiah atau rekayasa manusia (Nana Syaodih Sukmadinta, 2010: 72)

Jenis penelitian deskriptif kualitatif dipilih dimaksudkan untuk menjelaskan peristiwa atau kejadian yang ada saat penelitian berlangsung. Yaitu tentang "Sejarah perkembangan kesenian tari gaplik di Desa Kendung Kecamatan Kuwadungan tahun 1966-2014".

\section{Sumber Data}

Sumber data merupakan bagian yang sangat penting bagi peneliti karena ketepatan memilih dan menetukan jenis sumber data akan menetukan ketepatan dan kekayaan data atau kedalaman informasi yang diperoleh. Data tidak akan bisa diperoleh tanpa adanya sumber data. Betapun menariknya suatu permasalahan atau topik penelitian, bila sumber datanya tidak tersedia (Sutopo, 2006: 56).

Penelitian ini menggunakan sumber data sebagai berikut :

a. Sumber Data Primer

Sumber data primer merupakan data yang didapat dari sumber pertama baik dari individu atau perseorangan seperti hasil dari wawancara atau hasil pengisian kuesioner yang biasa dilakukan peneliti (Husein Umar, 2011: 42). 


\begin{abstract}
Sumber pertama dari penelitian ini berupa hasil wawancara dari saudara Hartono, yang terlibat langsung dalam tari gaplik sekaligus pewaris dari kesenian tari tersebut selain itu juga kepada tokoh masyarakat serta perangkat desa. Wawancara yang dilakukan mengenai awal terbentuknya tari gaplik dan sejarah perkembangan tari gaplik.
\end{abstract}

b. Sumber Data Sekunder

Sumber data sekunder merupakan data primer yang telah diolah lebih lanjut dan disajikan baik oleh pihak pengumpul data primer atau oleh pihak lainya misalnya dalam bentuk tabel-tabel atau digram-diagram (Husein Umar, 2011: 42). Dalam penelitian ini berupa sumber-sumber pustaka, selain sumber-sumber pustaka sumber sekunder di dapatkan melalui wawancara dengan kepala desa Kendung, perangkat desa dan beberapa masyarakat desa Kendung.

Masyarakat yang dipilih adalah yang terlibat langsung maupun tidak langsung terutama seperti pemain musik yang mengiringi tari gaplik dan orang-orang asli desa Kendung yang mengetahui tentang tari gaplik. sumber lain adalah dokumendokumen yang diambil dari kantor Desa Kendung.

\section{Teknik Pengumpulan Data}

Sesuai dengan pendekatan penelitian kualitatif serta jenis sumber data yang digunakan, maka menggunakan teknik pengumpulan data sebagai berikut:

1. Observasi

Observasi ialah pengamatan dan pencatatan yang sistematis terhadap gejala-gejala yang diteliti. Observasi menjadi salah satu teknik pengumpulan data apabila : (1) sesuai dengan tujuan penelitian, (2) direncanakan dan dicatat secara sistematis dan (3) dapat dikontrol keadaannya (reliabilitasnya) dan kesahihannya (validitasnya) (Husaini dan Purnomo, 2004: 54).

Ada beberapa jenis atau teknik dalam observasi disntaranya adalah observasi terbuka, observasi terfokus, observasi terstruktur, dan observasi sistematik. Diantara beberapa jenis yang telah disebutkan penelitian ini menggunakan jenis observasi terfokus. Observasi terfokus merupakan salah satu jenis pengamatan yang secara cukup spesifik mempunyai rujukan pada rumusan masalah atau tema penelitian (Basrowi dan Suwandi, 2008: 99).

Pada penelitian ini tujuan observasi atau pengamatan ini 
adalah untuk mengetahui bagaimana sejarah perkembangan kesenian tari gaplik. Hal-hal yang perlu diamati atau observasi diantaranya awal mula terbentuknya tari gaplik, perkembangan dalam setiap tahun, tantangan-tantangan yang dihadapi dalam setiap tahun.

2. Wawancara

Wawancara merupakan salah satu teknik pengumpulan data yang lain. Pelaksanaannya dapat dilakukan secara langsung berhadapan dengan yang diwawancarai, tetapi dapat juga secara tidak langsung seperti memberikan daftar pertanyaan untuk dijawab pada kesempatan lain instrumen dapat berupa pedoman wawancara maupun checklist (Husein Umar, 2011: 51).

Dalam penelitian ini bentuk wawancara yang digunakan adalah wawancara terstruktur pada penari tari gaplik, pemain musik yang mengiringi tari gaplik, sebagian masyarakat Desa Kendung, perangkat desa, serta tokoh masyarakat Desa Kendung. Alasan memilih jenis penelitian ini karena bersifat informal dan dapat direncanakan agar sesuai dengan subyek dan keadaan waktu wawancara dilakukan. Dalam bentuk wawancara ini kreatifitas penulis sangat penting dan dibutuhkan, karena peneliti bebas mengajukan pertanyaan dan jawaban yang didapatkan lebih luas dan bervariasi.

3. Dokumentasi

$$
\text { Sukardi }
$$$$
\text { (2003: }
$$

menjelaskan bahwa dokumentasi adalah cara lain memperoleh data dari responden. Peneliti memperoleh informasi dari bermacam-macam sumber tertulis atau dokumen yang ada pada responden atau tempat dan dimana responden bertempat tinggal atau melakukan kegiatan sehari-hari. Sumber dokumen yang ada dapat dibedakan menjadi dua macam yaitu dokumen resmi, termasuk surat keputusan, surat instruksi dan surat bukti kegiatan yang dikeluarkan oleh kantor organisasi yang bersangkutan seperti pada saat mengikuti perlombaan antar kesenian tradisional seJawa Timur atau saat melakukan pertunjukan dalam memperingati hari bersejarah, dan sumber yang tidak resmi yang mungkin berupa surat surat nota, surat pribadi yang memberikan informasi kuat terhadap suatu kejadian . 
Untuk mendukung penelitian ini, peneliti mengambil sumber dokumentasi sebagai berikut :

a. Arsip Dokumen

$$
\text { Arsip dokumen yang }
$$
digunakan adalah arsip, serta data-data yang dimiliki oleh desa Kendung. Arsip yang dimaksudkan adalah profil desa. Pada dokumen profil desa terdapat data-data pendukung penelitian, data tersebut berguna untuk menggali informasi mengenai keberadaan desa Kendung. Adanya dokumen tersebut peneliti terbantu ketika akan melakukan penelitian di desa Kendung.

b. Dokumen berupa Foto

Foto mengahasilkan data deskriptif yang cukup berharga dan sering digunakan untuk menelaah segi-segi subjektif dan hasilnya sering dianalisis secara induktif (Lexy Moeleng, 2012: 160). Dalam penelitian ini foto yang digunakan adalah foto-foto gerakan tari gaplik dan foto saat tari gaplik digunakan dalam acara bersih desa maupun saat perlombaan. Fotofoto yang didapatkan dari pewaris serta penari tari gaplik yaitu saudara Hartono.

\section{E. Prosedur Penelitian}

Penelitian tentang sejarah perkembangan kesenian tari Gaplik di desa Kendung kecamatan kuwadungan kabupaten Ngawi tahun 1966-2014 ini melalui berbagai tahap penelitian, diantaranya adalah sebagai berikut:

1. Tahap Persiapan

$$
\begin{aligned}
& \text { Pada tahap persiapan, } \\
& \text { penelitian dimulai dengan } \\
& \text { pencarian tema penelitian serta } \\
& \text { pengajuan judul pada bulan } \\
& \text { Februari. Setelah mendapat }
\end{aligned}
$$

2. Tahap Pelaksanaan

$$
\begin{aligned}
& \text { Kegiatan yang dilakukan } \\
& \text { dalam tahap ini } \text { adalah } \\
& \text { pengumpulan data dari lapangan. }
\end{aligned}
$$
Langkah awal untuk memperoleh data lapangan adalah mencari informasi di kantor desa agar dapat memperoleh data desa dan gambaran masyarakat. Selanjutnya dengan mencari informasi menggunakan teknik Purposive Sampling. Setelah data terkumpul maka dilakukan penyusunan data, 
serta menganalisis dan penyusunan laporan.

3. Tahap Penyelesaian

Tahap penyelesaian merupakan tahap akhir dari rangkaian penelitian. Kegiatan yang dilakukan pada tahap ini adalah penyusunan laporan yang telah mengalami berbagai revisi. Penelitian ini dapat diketahui melalui jadwal penelitian yang dimulai sejak pengajuan judul sampai kegiatan akhir yaitu penyusunan hasil penelitian yang telah melalui analisis dan berbagai revisi.

\section{F. Teknik Keabsahan Data}

$$
\begin{aligned}
& \text { Penelitian kualitatif sering } \\
& \text { mengalami permasalahan dalam } \\
& \text { keabsahan data. Penelitian kualitatif } \\
& \text { banyak yang diragukan kebenaranya } \\
& \text { dikarenakan : kurangnya kontrol } \\
& \text { dalam pelaksanaan wawancara dan } \\
& \text { observasi, serta sumber data kualitatif } \\
& \text { yang kurang kredibel yang akan } \\
& \text { mempengaruhi hasil penelitian. } \\
& \text { Kredibilatas data untuk membuktikan } \\
& \text { apa yang telah dikumpulkan sesuai atau } \\
& \text { tidak dengan kenyataan yang ada dalam } \\
& \text { latar penelitian. Pada penelitian ini, } \\
& \text { peneliti menggunakan teknik } \\
& \text { trianggulasi untuk menguji keabsahan } \\
& \text { data. } \\
& \text { Pada penelitian ini peneliti } \\
& \text { menggunakan trianggulasi sumber. }
\end{aligned}
$$

Menurut Sutopo (2006: 93) cara ini mengarahkan peneliti agar di dalam mengumpulkan data, wajib menggunakan sumber data berbedabeda yang tersedia. Artinya, data yang sama atau sejenis akan lebih mantap kebenaranya bila digali dari beberapa sumber data yang berbeda. Penelitian ini difokuskan terhadap sejarah perkembangan kesenian tari gaplik, sehingga hal ini memerlukan beberapa sumber yang berbeda untuk menggali informasi sehingga dapat membandingkan pandangan yang ada dalam masyarakat. Penggunaan trianggulasi ini diharapkan dapat membandingkan data yang telah diperoleh dari beberapa sumber yang berbeda-beda sehingga penggalian data dapat teruji kebenarannya dan menghasilkan data yang valid.

Trianggulasi sumber dapat dilihat dari bagan di bawah ini :

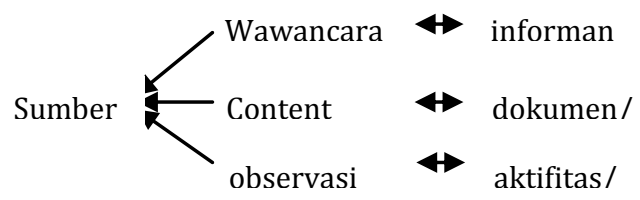

Bagan 3.1 Trianggulasi sumber (Sutopo, 2006:94)

\section{G. Teknik Analisis Data}

Analisis data merupakan proses mencari dan menyusun secara sistematis data yang diperoleh dari hasil wawancara, catatan lapangan, dan 
dokumentasi dengan cara mengorganisasikan data ke dalam kategori, menjabarkan ke dalam unitunit, melakukan sintesa, menyusun ke pola, memilih mana yang penting dan yang akan dipelajari dan membuat kesimpulan sehingga mudah dipahami oleh diri sendiri maupun orang lain (Sugiyono, 2009: 244). Analisis data dalam kualitatif dilakukan sejak sebelum memasuki lapangan, selama dilapangan dan setelah selesai dilapangan.

Sutopo (2006: 91-93) dalam proses analisis terdapat tiga komponen utama adalah 1). Reduksi data, 2). Sajian data, 3). Penarikan simpulan. Analisis data kualitatif model interaktif Miles dan Huberman, secara terperinci akan dijelaskan pada uraian berikut :

1. Reduksi Data

Reduksi data merupakan komponen pertama dalam analisis yang merupakan proses seleksi, pemfokusan,penyederhanaan dan abstraksi data dari fieldnote.

2. Sajian Data

Sajian data merupakan suatu rakitan organisasi informasi, deskripsi, dalam bentuk narasi yang memngkinkan simpulan penelitian dilakukan.

3. Penarikan Simpulan dan Verifikasi Langkah ketiga analisis data kualitatif model interaktif Miles dan
Huberman adalah penarikan simpulan dan verifikasi. Penarikan kesimpulan hanyalah sebagian dari satu kegiatan dari konfigurasi yang utuh. Kesimpulan-kesimpulan diverifikasi selama penelitian berlangsung.

Proses analisis data dapat dilihat pada bagan 3.2:

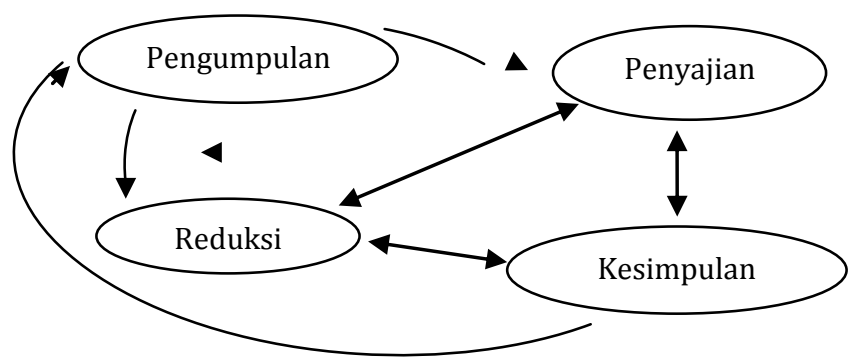

$\begin{array}{ccr}\text { Bagan 3.2 } & \text { Analisis Kualitatif } & \text { Model } \\ & \text { Interaktif (Miles dan } \\ & \text { Huberman 1992:20) }\end{array}$

Analisis merupakan proses dalam penelitian atau pencarian dan perencanaan secara sistematik semua data dan bahan lain yang terkumpul, agar peneliti bisa mengerti benar makna yang telah dikemukakan dan dapat menyajikan kepada yang lain dengan jelas.

\section{Hasil Penelitian}

1. Latar Belakang Terciptanya Tari Gaplik

Latar belakang terciptanya tari gaplik adalah sebagai salah satu pengisi acara pada bersih desa yaitu di desa Kendung khususnya. Acara ini diadakan setiap satu tahun sekali dengan 
memanjatkan do'a sebagai ucapan syukur atas hasil yang diperoleh masyarakat selama satu tahun, selain itu juga sebagai penghilang sesuker di desa. Gaplik itu menunjukan laki-laki tua yang jelek lik pada kata gaplik itu menunjukan arti elek. Namun menurut perkembangan zaman, singkatan gaplik saat ini adalah gambaran petunjuk liwat kesenian.

Dari hasil wawancara empat dari lima informan menjelaskan bahwa mereka tidak mengetahui kapan mulainya tari gaplik ini ditarikan dan siapa penciptanya, yang mereka ungkapkan hanya tari ini ada sejak zaman dahulu dari mereka masih kecil, dan tari ini sudah ada. Namun ada penjelasan berbeda dari salah satu informan yang menurutnya dahulu sebelumnya di desa Kendung ada pagebluk atau huru-hara, dan setelah diadakan tari gaplik semua musibahmusibah itu tidak kembali lagi dan keadaan menjadi lebih baik.

Orang yang pertama kali menarikan tari gaplik merupakan orang Mbayem yaitu salah satu desa yang letaknya tidak jauh dari Kendung. Disampaikan oleh informan bahwa setelah orang pertama yang menarikan tari gaplik tersebut meninggal dunia maka digantikan oleh cucunya. Namun pada tahun pertama setelah menarikan tari Gaplik di desa Kendung ternyata ada masyarakat yang kesurupan. Menurut kepercayaan masyarakat hal ini disebabkan karena penjaga punden di desa Kendung merasa penari ini tidak cocok atau tidak tepat dan meminta agar penari diganti dengan orang asli desa Kendung. Akhirnya masyarakat memilih saudara Kasno sebagai penari gaplik. Setelah tidak dapat menari lagi karena sakit saudara Kasno kemudian digantikan oleh putranya yaitu saudara Hartono yang masih menarikan tari Gaplik hingga sekarang.

2. Sejarah Perkembangan Tari gaplik

Tari gaplik merupakan salah satu kesenian tradisional yang masih mendapatkan perhatian hingga saat ini. Tari gaplik tidak berbeda dengan kesenian tradisional yang lain yang mengalami perkembangan dan tantangan dalam setiap perjalananya di era modern ini. Tari gaplik ditarikan dalam acara bersih desa, dahulu tari ini dipersembahkan setelah panen raya tepat pada Jumat wage tetapi sesuai perkembangan zaman sekarang ini tari gaplik ditampilkan pada bulan Agustus sekalian meramaikan hari ulang tahun kemerdekaan Indonesia tapi tetap di tampilkan pada hari Jumat wage.

Tari Gaplik memiliki gerakan dan musik yang menjadi pokok dan tidak boleh dirubah, namun selain gerakan pokok tersebut ada bagian dari 
tari yang bisa dikembangkan. Seperti yang dikatakan oleh para informan bahwa dalam tari gaplik ini tidak hanya sekedar tari dengan gerakan-gerakan tarian saja tetapi juga terdapat lelucon di dalamnya. Lelucon ini terselip dalam dialog antara penari gaplik dengan sinden atau disebut waranggono. Selain dengan waranggono dialog juga dilakukan dengan penonton. dari sini munculah hiburan yang menghibur penonton lewat lelucon yang dilontarkan. Tidak hanya itu tapi menurut yang disampaikan informan dibalik gerakan, musik dan lelucon yang ditampilkan tersebut terselip nasehat yang dapat dipetik oleh masyarakat.

Ada pendapat berbeda yang disampaikan oleh dua informan yang mengatakan bahwa tari gaplik saat ini berbeda jauh dengan tari gaplik pada masa sebelumnya. Ada beberapa gerakan dan dialog yang sudah berbeda dan dikurangi. Dahulu tari gaplik ditampilkan hampir satu jam lebih tapi sekarang hanya sekitar satu jam. Jadi kualitasnya dinilai menurun.

Seperti tari-tari yang lain tari gaplik juga memiliki pakaian khas yang digunakan setiap kali tampil. Selain pakaian wajib juga ada beberapa aksesoris yang khas dari tari gaplik ini. diantara pakaian dan aksesoris yang menjadi khas dari tari gaplik adalah caping basu londo, cemethi amarah suli, jemblek kotang onto kusumo, klinting Guntur bumi, kalung, kilat bahu, cakep (gelang tangan), epek (sabuk), boroboro Samir, sampur, sumping, parang (keris), binggel (gelang kaki), dan klinting.

Selain pakaian dan tarian yang khas tari gaplik juga memiliki musik atau iring-iringan tarian yang unik. Seperti sampak yaitu bunyi yang dibunyikan dari gong yang digunakan untuk mengiringi jalan saat penari masuk, soyang, dan kudangan, setelah kudangan selesai selanjutnya menyanyikan lagu bebas, lagu bebas ini dinyanyikan setelah tarian wajib dari tari gaplik sudah di tampilkan semua. Lagu bebas disini digunakan sebagai hiburan atau senang-senang.

Menurut para informan tari gaplik ini ditarikan dalam acara bersih desa atau nyadran. Dahulu saat bersih desa tari gaplik ditarikan sampai dua kali dalam satu hari. Pertama ditarikan di punden pada siang hari yang dikenal dengan makam mbah Budho oleh masyarakat. Kemudian kedua pada malam harinya ditarikan di rumah kepala desa. Namun seperti yang dituturkan para informan, saat ini tari gaplik hanya ditarikan satu kali yaitu pada malam hari. Tempatnya juga tidak lagi di punden tetapi di pendopo yang telah dibangun didekat pasar. Menurut 
pendapat yang diterangkan oleh informan hal ini disebabkan adanya penyalahgunaan punden yang digunakan sebagai tempat sesembahan hingga akhirnya kepala desa merubah bangunan punden menjadi seperti makam biasa.

Tari gaplik mulai mengundang ketertarikan masyarakat desa lain untuk menyaksikannya. Adanya ketertarikan dari masyarakat luar dikarenakan tari gaplik tidak hanya menampilkan tarian saja namun juga terdapat cerita dan lelucon yang dapat menghibur penontonnya, selain itu tari gaplik juga memiliki keunikan yaitu adanya dialog dengan penonton sehingga menambah semangat dan hiburan bagi mereka. Dari ketertarikan tersebut menjadikan tari gaplik semakin dikenal dan mendapat tawaran untuk mengisi acara bersih desa di desa-desa yang lain. Tari gaplik yang biasanya hanya dipentaskan satu tahun sekali saat bersih desa di desa Kendung sekarang mulai ditampilkan dalam acara-acara Nyadran di desadesa yang lain. Diantara beberapa desa yang ikut menampilkan tari gaplik tersebut adalah desa Mbayem, desa Kincang kabupaten Magetan, desa Suratmajan Maospati, dan desa Kinandang kabupaten Magetan. Hingga saat ini pada setiap tahunnya desa Mbayem dan Kinandang tersebut mengundang tari gaplik untuk ditampilkan dalam acara bersih desa di desanya.

Seiring perkembangan zaman yang modern ini sedikit banyak membawa pengaruh terhadap kemajuan bagi tari gaplik sebagai tari tradisional. Kemajuan ini mulai tampak ketika tahun 2005 tari gaplik mulai mewakili kota Ngawi dalam festival kesenian tradisional di Surabaya. Pada tahun berikutnya yaitu tepatnya januari 2006 tari gaplik kembali mengikuti festival kesenian tradisional se jawa timur di Surabaya. Dua kali mengikuti perlombaan akhirnya pada tahun 2008 tari gaplik dipercaya kembali dan diikut sertakan dalam lomba kesenian tradisional se Jawa Timur di Bojonegoro. Berkali-kali mengikuti lomba menjadikan tari gaplik semakin dikenal luas oleh masyarakat se Jawa Timur, dan untuk ke empat kalinya tari gaplik kembali diikutkan dalam lomba pada Agustus 2010 di Kediri. Setelah dikenal luas oleh masyarakat dan menjadi tari tradisional yang menghibur dan menarik banyak penonton, pada bulan Juni 2014 tari gaplik ditampilkan dalam hari jadi kota Ngawi pada bulan di Benteng Pendem.

Ada beberapa kendala yang dihadapi dalam melestarikan tari gaplik ini menurut beberapa informan kendala ini muncul karena kurangnya 
kreatifitas penari itu sendiri. Pendapat ini diperkuat dengan pendapat lain yang mengatakan latar belakang pendidikan yang kurang dari penari itu sendiri sehingga bila diajarkan materi yang baru kurang cepat dalam menerima.

Selain pendapat diatas ada informan yang mengatakan bahwa tidak ada masalah dan kendala berarti yang dihadapi. Karena tari gaplik ini sendiri ditarikan hanya satu tahun sekali dan tetap dilaksanakan hingga saat ini. Tari gaplik merupakan tari yang sudah lama ada sebelum Indonesia merdeka. Namun meskipun tari ini merupakan tari yang sudah sangat lama tidak mengurangi antusias penonton dalam setiap tahunnya.

Melihat banyak kesenian yang muncul seperti ludruk dan ketoprak yang pernah jaya, hal tersebut juga tidak membawa pengaruh terhadap minat para penonton untuk menyaksikan tari gaplik. Menurut salah seorang informan minat penonton pertunjukan tari ini dapat mengalahkan pertunjukan ludruk dan ketoprak saat itu. Tari gaplik juga tidak mengandung unsur politik di dalamnya sehingga saat kesenian lain menuai permasalahan dengan pemerintah tari gaplik tidak ikut di dalamnya.

Minat penonton dalam setiap tahunnya hingga sekarang juga sangat ramai dan antusias, tidak hanya dari masyarakat sekitar tetapi masyarakat desa lain juga ikut menyaksikannya. Menurut penuturan salah serang informan bahwa tari gaplik ini di Ngawi penontonnya paling banyak untuk pertunjukan kesenian tradisional.

Tari gaplik ini boleh ditarikan oleh siapa saja dengan catatan dia memang bisa menari, memiliki keberanian, dan ditambahkan lagi oleh informan yang lain bahwa orang tersebut harus lucu. Dari kelima informan ada satu pendapat yang berbeda menurutnya tari gaplik ini hanya boleh ditarikan oleh keturunan dari penari-penari sebelumnya, dan penari tersebut harus disukai oleh mbah Budho.

Dalam hal susunan gerakan tari gaplik, beberapa informan menuturkan pendapat yang sama. Pertama, penari keluar panggung seperti orang tua dengan dandanan seperti punokawan dan membawa teken atau tongkat. Jalan membungkuk diantar orang dengan membawa obor. Kedua, melecutkan cemethi amarah suli dilanjutkan joget lawong dan memanggil waranggono, setelah waranggono masuk antara pakgaplik dan waranggono mengatakan tujuan mereka pentas disitu. Setelah itu pak gaplik gandrung dan merayu waranggono, tetapi waranggono tidak mau karena pak.gaplik jelek. Setelah itu 
pak gaplik menunjukan semua kesaktian yang dimilikinya untuk meraih hati waranggono tersebut. setelah selesai waranggono menjadi gandrung dan akhirnya melakukan kudangan, kudangan ini merupakan ungkapan pujian waranggono kepada pakgaplik.

Pesan yang ingin disampaikan dalam tari ini adalah mengajak masyarakat agar rukun dan damai. Ditambahkan oleh salah seorang informan yaitu pesan yang ingin disampaikan selain rukun, damai, baik dalam rumah tangga maupun bermasyarakat juga tanggung jawab dan mempunyai pekerjaan.

\section{Pembahasan}

\section{Latar Belakang Terciptanya Tari Gaplik}

Tari gaplik merupakan salah satu kesenian tradisional yang berasal dari Desa Kendung Kecamatan Kwadungan Kabupaten Ngawi. Keberadaan tari gaplik diperkirakan sudah ada sejak Indonesia belum merdeka dan penciptanya tidak diketahui. Tari gaplik digunakan sebagai salah satu pengisi acara yang wajib pada bersih desa yaitu di Desa Kendung khususnya. Gaplik ini merupakan singkatan dari gambaran petunjuk liwat kesenian. Sesuai hasil keterangan yang didapatkan dari lapangan latar belakang ditarikannya tari ini karena desa Kendung mengalami bencana pagebluk dan huru hara, dan setelah diadakan tari gaplik semua musibah-musibah itu tidak kembali lagi dan keadaan menjadi lebih baik. Sehingga tari gaplik terus ditarikan saat acara bersih desa atau nyadran. Koentjaraningrat (dalam Tjetjep Rohendi, 2000: 3) mengungkapkan kesenian telah menyertai kehidupan manusia sejak awal-awal kehidupan dan sekaligus merupakan bagian yang tak terpisahkan dari seluruh kehidupan manusia.

Tari gaplik ini merupakan jenis kesenian yang turun temurun. Orang yang pertama menarikannya berasal dari Desa Mbayem, tetapi tidak diketahui namanya. Setelah orang pertama yang menarikannya meninggal dunia maka digantikan oleh penerusnya. Namun pada tahun pertama setelah menarikan tari gaplik di Desa Kendung ternyata ada masyarakat yang kesurupan. Menurut kepercayaan masyarakat, hal ini disebabkan karena penjaga punden di Desa Kendung merasa penari ini tidak cocok atau tidak tepat dan meminta agar penari diganti dengan orang asli Desa Kendung. Akhirnya masyarakat memilih saudara Kasno sebagai penari gaplik. Setelah tidak dapat menari lagi karena sakit saudara Kasno kemudian digantikan oleh putranya yaitu saudara Hartono yang masih menarikan tari Gaplik hingga sekarang.

Dahulu tari ini dipersembahkan tepat pada Jumat Wage setelah panen raya, tetapi sesuai perkembangan zaman sekarang ini tari gaplik ditampilkan pada bulan Agustus 
dibarengkan dengan perayaan hari ulang tahun kemerdekaan Indonesia namun tetap di tampilkan pada hari Jumat Wage. Hal ini sesuai keterangan yang diperoleh bahwa pada tahun ini tari gaplik sudah dijadwalkan akan diadakan pada tanggal 8 Agustus 2014 tepat pada Jumat Wage. Seperti yang diungkapkan Ferianto (dalam Juju Masunah dan Tati Narawati, 2003: 133) sebuah tradisi tidak pernah berhenti. Ia senantiasa berkembang bersama dengan situasi dan konteks sosial yang melingkupinya. Tidak pernah ada suatu tradisi yang tidak berubah. Jika ada tradisi yang tidak berubah berarti tradisi tersebut telah selesai bahkan mati.

\section{Sejarah Perkembangan Tari Gaplik}

Tari gaplik merupakan salah satu kesenian tradisionl yang masih memiliki perhatian dan minat yang tinggi dari masyarakat hingga saat ini, khususnya dari masyarakat dasa Kendung yang merupakan masyarakat pemilik kesenian daerah ini. Masyarakat desa kendung mengatakan bahwa Tari gaplik menjadi salah satu pengisi acara yang wajib dilakukan dalam bersih desa setiap tahunnya. Hal tersebut senada dengan ungkapan Tjetjep Rohandi Rohidi (2000: 209) yaitu kesenian lokal yang secara umum dikenal sebagai kesenian tradisional adalah jenis kesenian yang hidup dominan dikalangan suku bangsa tertentu. Kesenian tradisional menjadi bagian dari kehidupan secara menyeluruh dalam upacara-upacara ritual kehidupan.

Tari Gaplik memiliki gerakan dan musik yang menjadi baku tidak boleh dirubah. Diantara gerakan pokok tersebut adalah Pertama, penari yang disebut dengan Pak Gaplik keluar panggung seperti orang tua dengan dandanan seperti punokawan dan membawa tongkat, berjalan dengan membungkuk untuk diantar orang dengan membawa obor. Kedua, duduk lalu melecutkan cemethi amarah suli (cambuk) dilanjutkan joget lawong dan memanggil waranggono. Ketiga setelah waranggono masuk antara Pak Gaplik dan waranggono mengatakan tujuan mereka pentas disitu. Keempat Pak Gaplik gandrung dan merayu waranggono, tetapi waranggono tidak mau karena Pak Gaplik jelek.

Kelima Pak Gaplik menunjukan semua kesaktian yang dimilikinya untuk meraih hati waranggono tersebut. setelah selesai waranggono menjadi gandrung kemudian Pak Gaplik minta dinyanyikan lagu godril dan gorang-gareng, setelah selesai akhirnya melakukan kudangan, kudangan ini merupakan ungkapan pujian waranggono kepada Pak Gaplik tanda bahwa waranggono juga menyukai Pak Gaplik.

Alat utama musik dalam tari gaplik ini adalah sampak yaitu bunyi yang dibunyikan dari gong yang digunakan untuk mengiringi jalan saat penari masuk, soyang, dan kudangan, setelah kudangan selesai selanjutnya menyanyikan lagu bebas, lagu 
bebas ini dinyanyikan setelah tarian wajib dari tari gaplik sudah di tampilkan semua. Lagu bebas disini digunakan sebagai hiburan atau senang-senang.

Tari gaplik memiliki pakaian khas yang digunakan setiap kali tampil. Selain pakaian khas juga ada beberapa aksesoris yang khas dari tari gaplik ini. diantara pakaian dan aksesoris yang menjadi khas dari tari gaplik adalah caping basu londo, cemethi amarah suli, jemblek kotang onto kusumo, klinting Guntur bumi, kalung, kilat bahu, cakep (gelang tangan), epek (sabuk), boro-boro Samir, sampur, sumping, parang (keris), binggel (gelang kaki), dan klinting.

Tari gaplik ini tidak hanya sekedar tari dengan gerakan-gerakan tarian saja tetapi juga terdapat lelucon di dalamnya. Lelucon ini terselip dalam dialog antara penari gaplik dengan sinden atau disebut waranggono. Selain dengan waranggono dialog juga dilakukan dengan penonton. dari sini munculah hiburan yang menghibur penonton lewat lelucon yang dilontarkan. Diantara gerakan dan musik yang menjadi pokok dari tari gaplik dan tidak boleh dirubah di atas, ada bagian dari tari yang bisa dikembangkan yaitu pada lelucon yang terselip dalam dialog antara penari gaplik dengan sinden atau disebut waranggono.

Sebelum pergantian kepala desa pada tahun 1988 setiap acara bersih desa tari gaplik ditarikan dua kali dalam satu hari tepat pada hari Jumat wage setelah panen raya. Pertama ditarikan di punden pada siang hari. Kemudian kedua pada malam harinya ditarikan di rumah kepala desa. Namun saat ini tari gaplik hanya ditarikan satu kali yaitu pada malam hari. Tempatnya juga tidak lagi di punden tetapi di pendopo yang telah dibangun didekat pasar, hal ini disebabkan adanya penyalahgunaan punden yang digunakan sebagai tempat sesembahan hingga akhirnya kepala desa merubah bangunan punden menjadi seperti makam biasa.

Tari gaplik mulai menarik perhatian masyarakat desa lain untuk menyaksikannya. Adanya ketertarikan tersebut dikarenakan tari gaplik tidak hanya menampilkan tarian saja namun juga terdapat cerita dan lelucon yang dapat menghibur penontonnya, selain itu tari gaplik juga memiliki keunikan yaitu adanya dialog dengan penonton sehingga menambah semangat dan hiburan bagi mereka.

Dari ketertarikan tersebut menjadikan tari gaplik semakin dikenal dan mendapat tawaran untuk mengisi acara bersih desa di desa-desa yang lain. Tari gaplik yang biasanya dipentaskan satu tahun sekali saat bersih desa di Desa Kendung, maka pada tahun 1966 mulai ditampilkan dalam acaraacara Nyadran di desa-desa yang lain. Diantara beberapa desa yang ikut menampilkan tari gaplik tersebut adalah desa Mbayem, desa Kincang kabupaten Magetan, desa Suratmajan Maospati, dan desa Kinandang kabupaten Magetan. Hingga 
saat ini pada setiap tahunnya desa Mbayem dan Kinandang tersebut mengundang tari gaplik untuk ditampilkan dalam acara bersih desa di desanya. Seperti halnya temuan yang ada dilapangan bahwa desa Mbayem sendiri tahun ini sudah melakukan konfirmasi dengan pihak desa Kendung untuk mengisi acara tari gaplik pada Agustus mendatang.

Seiring dengan perkembangan zaman membawa pengaruh terhadap kemajuan bagi tari gaplik sebagai tari tradisional. Kemajuan ini mulai nampak pada tahun 2005 ketika tari gaplik mulai mewakili kota Ngawi dalam festival kesenian tradisional di Surabaya. Kemudian pada bulan januari 2006 tari gaplik kembali mengikuti festival kesenian tradisional se jawa timur di Surabaya.

Kemudian setelah itu pada tahun 2008 tari gaplik dipercaya kembali dan diikut sertakan dalam lomba kesenian tradisional se Jawa Timur di Bojonegoro. oleh karena seringnya mengikuti lomba menjadikan tari gaplik semakin dikenal luas oleh masyarakat se Jawa Timur, dan untuk ke empat kalinya tari gaplik kembali diikutkan dalam lomba pada Agustus 2010 di Kediri. Setelah dikenal luas oleh masyarakat dan menjadi tari tradisional yang menghibur dan menarik banyak penonton, pada bulan Juni tari gaplik ditampilkan dalam hari jadi kota Ngawi di Benteng Pendem.

Ada beberapa kendala yang dihadapi dalam melestarikan tari gaplik ini, terutama dari faktor intern yaitu kurang adanya kreatifitas dari penari itu sendiri. Menurut penjelasan yang didapat hal ini disebabkan latar belakang pendidikan yang kurang dari penari sehingga menjadi penghambat dalam pengembangan materi dialog.

Melihat kendala yang ada seperti ini sebaiknya pihak pemerintah desa membantu para seniman yang ada dengan memberikan wawasan kepada mereka sesuai dengan materi yang sesuai dengan keadaan saat ini, agar dari seniman sendiri lebih mudah dalam menyampaikan serta mengembangkan dialognya. Selain itu juga mengadakan pelatihan pada penari gaplik sehingga memudahkan penari dalam berlatih. Ayu Sutarto (2004: 2) juga mengungkapkan saat ini yang terjadi adalah bahwa banyak jenis kesenian tradisional yang sekarang ini sekarat atau bahkan mati. Terdapat dua faktor mengapa hal itu terjadi yaitu faktor yang berasal dari luar (faktor eksternal) dan yang berasal dari dalam dirinya (faktor internal)).

Meskipun tari gaplik merupakan tari yang sudah ada sebelum Indonesia merdeka. Namun minat penonton terhadap tari ini cukup banyak dalam pertunjukan setiap tahunnya, tidak hanya dari masyarakat desa Kendung tetapi masyarakat desa lain juga ikut menyaksikannya. Tari gaplik merupakan salah satu tari yang penontonnya paling banyak untuk pertunjukan kesenian tradisional di Ngawi. Pesan yang ingin 
disampaikan dalam tari ini adalah mengajak masyarakat agar rukun dan damai, juga tanggung jawab. Selain rukun, damai dalam rumah tangga juga rukun damai dalam bermasyarakat.

\section{Daftar Pustaka}

Alo Liliweri. 2007. Dasar-dasar Komunikasi Antar Budaya. Yogyakarta: Pustaka Pelajar

Ayu Sutarto. 2004. Menguak Pergumulan Antara Seni, Politik, Islam, dan Indonesia. Jember: Kelompok Pedui Budaya dan Wisata Daerah Jawa Timur (Kompyawisda)

Basrowi dan Suwandi. 2008. Memahami Penelitian Kualitatif. Jakarta: Rineka Cipta

Edi Sedyawati. 2007. Budaya Indonesia Kajian Arkeologi, Seni, dan Sejarah. Jakarta: PT Raja Grafindo Persada

Elly M. Setiadi, dkk. 2007. Ilmu Sosial dan Budaya Dasar. Jakarta: Kencana

H.B. Sutopo. 2006. Metodologi Penelitian Kualitatif Dasar Teori dan Terapannya Dalam Penelitian. Surakarta: Universitas Sebelas Maret

Husain Umar. 2011. Metode Penelitian untuk Skripsi dan Tesis Bisnis Edisi Kedua. Jakarta: PT Raja Grafindo Persada

Husaini Usman dan Purnomo Setiady Akbar. 2004. Metodologi Penelitian Sosial. Jakarta: Bumi Aksara

Juju Masunah dan Tati Narawati. 2003. Seni dan Pendidikan Seni. Bandung: Pusat Penelitian dan Pengembangan Pendidikan Seni Tradisional

Lexy J. Moleong. 2012. Metodologi Penelitian Kuallitatif. Bandung: PT Remaja Rosdakarya

Milles Matthew. B dan A. Michael Huberman. 1992. Analisis Data Kualitatif. Jakarta: Universitas Indonesia

Nana Syaodih Sukmadinata. 2010. Metode Penelitian Pendidikan. Bandung: PT Remaja Rosdakarya
Nooryan Bahari. 2008. Kritik Seni Wacana Apresiasi dan Kreasi. Yogyakarta: Pustaka Pelajar

Soedarsono. 2010. Seni Pertunjukan Indonesia di Era Globalisasi. Yogyakarta: Gadjah Mada University Press

Sugiyono. 2009. Metode Penelitian Kuantitatif, Kualitatif, dan R\&D. Bandung: Alfabeta

Sukardi. 2003. Metodologi Penelitian Pendidikan Kompetensi dan Praktiknya. Jakarta: PT BUMI AKSARA

Tjetjep Rohendi. 2000. Kesenian dalam Pendekatan Kebudayaan. Bandung: ACCENT Graphic Communication 